\title{
Epizootic Landscapes: Sheep Scab and Regional Environment in England in 1279-80
}

\author{
Philip Slavin \\ University of Kent \\ p.slavin@kent.ac.uk
}

\begin{abstract}
This essay looks at late-medieval rural landscapes of animal disease through the prism of sheep epizootics in England, caused by sheep scab, a highly acute and transmissive disease, whose first wave broke out in 1279-80. The essay focuses on three regions in England: East Anglia, the Wiltshire-Hampshire Chalklands and Kent, each possessing distinct topographic and environmental features and exhibiting different rates of mortality. The study sets a theoretical model, based on the concept of 'complexity theory' and consisting of ten different principles, determining regional variances in dissemination of scab and in mortality patterns. A close analysis of the available statistical sources suggests that there was no 'universal' explanatory factor accounting for the correlation between regional geography and mortality rates, and that the situation varied not only from region to region, but from farm to farm, depending on a combination of several possible factors. It is only through a meticulous analysis of local, rather than regional, conditions that we can start appreciating the complexity of the situation.
\end{abstract}

Keywords Late-medieval England; animal disease; scab; sheep economy; Complexity Theory

\section{Introduction}

In recent years there has been growing scholarly awareness of the concept of 'landscapes of disease' in relation to both humans and animals. Examples include studies on the impact (at the height of the 2001 Foot-and-Mouth Disease outbreak in Britain) of epizootic disease on British rural landscapes (Potter et al. 2001), on natural and anthropogenic landscapes encouraging the spread of zoonotic diseases in the transboundary region of the Rio Grande (the US-Mexico border) (Esteve-Gassent et al. 2014) and more generally on landscaperelated factors influencing the dissemination of pathogens (Lambin et al. 2010). A common characteristic of such pioneering studies is that they study contemporary rather than historic landscapes. There is a growing body of literature on historic 'landscapes of health' (or, 'healthscapes') in late-medieval and early modern urban Europe (Rawcliffe 2013; Geltner 2014; , Fay 2015), but the historic landscapes of disease (and especially of animal disease) in rural contexts are largely left out with very few notable exceptions (Newfield 2013). This paper addresses late-medieval rural landscapes of animal disease through the prism of sheep epizootics in England caused by scab (a highly acute and transmissive form of dermatitis brought about by mite infestation), first documented in England in 1279-80 (Slavin 
2015b). The study is divided into several parts. After an introduction to the sources on which the study is based, the wider environmental context in which scab originated is surveyed. In order to appreciate the chronological and demographic variances in scab landscape, I put forth a theoretical model, based on 10 propositions, representing exogenous and endogenous variables. This model resembles the ten principles of landscape epidemiology proposed by Lambin et al. (2010). To test it, I survey manorial documents in three regional cases of scab outbreak: East Anglia, the Wiltshire-Hampshire Chalklands and Kent (Figure 1). Close analysis of each case indicates no clear correlation between a single 'universal' factor and mortality rates. The situation varied not only from region to region but in fact from farm to farm, depending on a combination of several possible factors dictated by local exogenous and endogenous conditions. This strengthens the value of the 'complexity theory', stressing the inability to reduce any explanation to a single or few variables and the importance of analysing regional and even local contexts. Such an approach is utilised by both economists and environmental scientists (Flaherty 2014).

Place Fig 1 near here (Regional distribution of manors analysed in the study)

\section{Sources and a sample size}

The study is based on 64 manorial accounts for the account year of 1279-80. Manorial accounts were annual financial and agricultural reports of seigniorial estates, rendered on an audit basis, by local officials. As a rule, the accounts ran between two Michaelmases (29 September), recording, among other things, the incoming and outgoing patterns of local livestock, including seasonal trends of sheep deaths. The geographic distribution of this paper's sample is pronouncedly uneven, with most accounts referring to manors in south, south-east and east England (Map 1). Two factors, both institutional in their nature, stand behind this uneven distribution: manorialism has never been fully developed in northern and western parts of the country, while the thickest geographic coverage is closely associated with particular lordships whose archives have high survival rates, notably Winchester and Canterbury Cathedrals,

Manorial accounts deal only with the lords' production, which accounted for only about 20 per cent of late-medieval English agriculture (Broadberry et al. 2015). The remaining 80 per cent was produced by local peasant farms, of which our knowledge is less than satisfactory because of the scarce nature of evidence. Within the sheep sector, peasant farms occupied an even a larger share, as reflected in wool export accounts, whose high figures suggest that only a fraction could have been produced by demesnes (Slavin, 2015a). There is no comparably rich documentation for peasant livestock husbandry, and, as a result, the figures, estimates and calculations below derive from the seigniorial sector. All the same, the following discussion endeavours to account for both the demesne and tenant sectors. To fill some obvious gaps, an extensive use has been made of surviving lay subsidy rolls, recording the possessions of taxed households on parish-by-parish level. We may also assume that within an individual manor the morbidity and mortality figures will have been somewhat similar across both sectors, because in many instances, according to local custom 
in both East Anglia and the Chalklands (and possibly in some parts of east and north Kent) peasant-owned sheep were folded together with the lord's sheep on demesne fallow.

\section{Climate change and sheep epizootics in the late thirteenth century}

Although pre-thirteenth century agricultural sources are sparse, it appears that the outbreaks of sheep epizootics were uncommon before the thirteenth century, especially when compared to the incidence of human and cattle diseases (Newfield 2013). The outbreaks of sheep murrain, whose character is unknown, in 1201, 1225 and 1258 seem to be regional rather than national in character. The extent and proportions of sheep disease changed in 1279, with the arrival of the 'national' outbreak of scab in the thirteenth-century, which, within a space of just over one year killed almost half of England's sheep (Slavin 2015b). There are no statistical data for the earlier periods and hence it is impossible to determine whether this was the first historical outbreak of scab on the national level. Although the major wave of scab was over by 1281, there were minor recurrent outbreaks of scab well into the $1320 \mathrm{~s}$.

Scab is a highly acute and transmissive form of dermatitis, caused by the faeces and bites of non-burrowing sheep mites (Psoroptes ovis). The two-week lifecycle evolves from the egg, through hexapod larvae, octopod protonymphs and tritonymphs into adult mites. After mating and fertilising, female mites will live for some 40 days, laying one or two eggs a day and never mating again (Bates 2007). In appropriately cold temperatures ( 10 C), the mites can be viable off the host for 17 days (in wool sacks, woollen clothes, barns and soil), during which period eggs can hatch. Off-host longevity is shorter in warmer temperatures (Coop, Barger and Jackson 2002; Meintjes, Fourie and Horak 2002).

In order to appreciate the sudden appearance of pathogens, it is vital to appreciate the wider climatic and environmental context of the period (Campbell 2016). Shifts in ecological and climatic regimes can strongly influence biological attributes of living organisms (Ben Ari et al. 2011). There is a scholarly consensus that by c.1250-70 there were some visible climatic changes. After a century dominated by warm climate (the Medieval Climate Anomaly, or MCA), when average annual temperatures reached those ca. $2000 \mathrm{CE}$, the North Atlantic region entered a transitional phase from the MCA to the Little Ice Age (LIA). This transition was characterised by a high degree of instability in year-to-year temperature and precipitation levels, a high incidence of short-term weather anomalies and gradual cooling. Perhaps it would be fair to open that transitional phase with the eruption of Samalas (Indonesia) in 1257, the single largest volcanic eruption in the last 7,000 years, which released between 300 and 600 megatons of sulfuric acid (Stothers 2000, Lavigne et al 2013). In addition to the Samalas eruption, there were two additional (unidentified) eruptions in 1268 and 1275, releasing approximately 10 and 4 times less sulfuric acid than the 1257 volcano (Sigl et al. 2015). The volcanic eruptions were followed by a long-term depression in solar irradiance between c.1280-1340, a period known as the 'Wolf Minimum' (Muscheler et al. 2007).

It was in this climatic context that the scab outbreak of $1279-80$ originated. It seems to have been confined to the British Isles (Newfield 2009; Slavin 2012; Slavin 2015b), where the years of 1273, 1275, 1278 and 1280 were wet and cold (Britton, 1937), presenting the 
ideal conditions for the aggressive activity, mating and egg-laying of scab mites. It is possible that the 1270s were the enzootic phase in the scab cycle, when the mite population grew, encouraged by the favourable weather conditions, without attacking sheep. Sheep is the only reservoir of the disease in the British Isles, and mild and local infestations in healthy flocks had been reported before the outbreak in 1279 (for instance, in 1231-2 at East Meon, Hampshire and 1272-3 at East Knoyle, Wiltshire) (Slavin 2015b). By early 1279 the scab cycle had transformed from the enzootic to epizootic form, with first flocks succumbing in February or early March. As I have shown elsewhere, in the course of about 18 months, English demesnes lost almost half of their sheep (Slavin 2015b). It is unclear whether these figures reflect both the demesne and tenancy sectors, but given the physical proximity between the seigniorial and peasant flocks (especially, in these instances, when tenant animals were folding on the demesne fallow) may imply that the situation was equally grave across both sectors. The outbreak was also reported in east Wales and east Ireland in 1280-1, but it is unclear if the disaster prevailed in Scotland and other Celtic parts of the British Isles (Slavin 2015b).

The mortality rates varied between regions (Table 1) and topography (Table 2). Because of the rather unsatisfactory nature of the available evidence, it was possible to create only three regional clusters: East Anglia (comprising the counties of Norfolk, Suffolk and Essex), the Hampshire-Wiltshire Chalklands and Kent. As Table 1 shows, mortality rates and patterns varied across space. Thus, on 14 East-Anglian manors the mortality rates stood at 53 per cent, a figure above average (47 per cent). Rates on Chalkland manors were very similar to those in East Anglia, albeit the coefficient of variance (CoV) was higher, standing at 0.445. This indicates a more uneven skewness of mortality rates, with 5 manors experiencing the figures between 70 and 90 per cent, 6 manors exhibiting the figures between 40 and 55 per cent, and 11 manors getting away with lighter mortality rates of less than 40 per cent. An altogether different situation prevailed in Kent, where, sheer mortality rates were lower, standing at 36 per cent, while the $\mathrm{CoV}$ was even higher (0.706), indicating even greater differences across manors.

Place Table 1 near here

In other words, there were profound differences not only across regions, but also across manors. This undoubtedly indicates the complexity of the situation, which cannot be explained by one or two variables. In order to understand the seasonal and geographic variances in the spread of scab, it is necessary to consider various factors, both exogenous and anthropogenic, which determined the dissemination patterns of the disease and mortality rates in flocks, which, in turn, shaped the contours of the 'landscapes of epizootics'. Each factor will be treated separately, in conjunction with the analysis of regional and local peculiarities.

\section{Ten possible factors accounting for scab dissemination and mortality rates}

\section{Seasonality}

52 percent of all deaths occurred between October 1279 and February 1280, with the vast majority of all fatalities reported by June 1280. The predominance of winter deaths is hardly surprising: scab is primarily a winter disease, with scab-mites favouring cold and damp 
weather. Equally important, mite activity and, thus, the spread of the disease were also encouraged by the seasonal patterns of sheep management. During the winter months, sheep were densely concentrated in stone or timber sheepcotes. These structures played an important role in late-medieval sheep rearing (Dyer 1995). Once inside the sheepcotes, the diseased animals would rub themselves against the walls and edges of the sheepcotes. To make things even worse, placing diseased sheep together inside a sheepcote was encouraged by a contemporary liturgical practice, composed around 1280 to cope with the outbreak of scab. In the course of the service, with scabious sheep gathered in a sheepcote, several Gospel passages were read by a parish priest, sprinkling holy water at the end of his reading (Jordan 2009). Although the new practice intended to cure the disease, its suggestion to concentrate all the diseased sheep in a single edifice would undoubtedly expedite the spread of the disease.

In other words, the seasonality of scab, seasonal patterns of sheep management and contemporary religious practises created, together, a perfect connectivity of habitats for both mites and hosts. Moreover, sheep tend to be more prone to diseases during cold weather of the winter, when they have to spend more energy to maintain body heat, and when little or no grass grows, rendering animals to potential malnourishment. In other words, the spread of disease was not only dictated by the abundance of insects and hosts, but also by other natural and anthropogenic factors.

\section{Regional microclimates and topography}

Although broad climatic shifts played a central role in creating the environmental context for the transformation of scab from an enzootic to a epizootic phase, to understand the geographic patterns of its dissemination it is equally vital to bear in mind regional climatic and ecological peculiarities. Roughly oversimplifying, higher settlements tend to have higher incidence of precipitation and colder temperatures. On the other hand, proximity to sea can be another factor: for instance, coastal areas of eastern Norfolk, despite being flat, experience cold winter spells from cold northerly airstreams over the North Sea. Regions with wetter and colder winters may experience higher incidence of scab outbreaks and higher mortality rates; during the 2003-4 scab outbreak, Wales, Scotland and North England saw the highest incidence of the disease, while the east and south-west of England experienced the lowest (Bisdorff et al. 2006).

The surviving manorial accounts reveal that East Anglia was one of the first regions to be devastated by the scab epizootic. According to several 1278-9 accounts from Norfolk and Essex, the disease hit some East Anglian manors in early 1279, before lambing, commencing in late February or early March. The cold winters of East Anglia were all the more pronounced in the wider context of the cooling and wet events of the 1270s perhaps transforming scab from the enzootic to the epizootic form in early 1279. During these cold months of the year, sheep would be kept in cotes, which would mean a close physical contact between animals and a faster dissemination of the disease.

Similarly, the relatively wet climate of the Hampshire-Wiltshire Chalklands, caused by North-Atlantic depressions and the Azores high pressure, could be a decisive factor in encouraging mite activity. In the case of Kent, on the other hand, the climatic impact seems 
to have been less pronounced. Despite the continental climate, characterised by cold winters, the average mortality rates were lower than elsewhere in the country. In other words, the impact of regional climate on the disaster should not be taken for granted.

Another environmental factor to be considered is regional topography. The Chalklands are generally a hilly region, whose altitude varies from about 30 and 152 metres (100 to 500 feet) above sea level. The average altitude of the 22 Chalkland manors in this study is 86 metres (281 feet). Conversely, East Anglia and Kent (with the exception of the North Downs), are generally flat regions (the average elevation of twelve Kentish manors and fourteen East Anglian manors used in the study is 30 and 38 metres (97 and 123 feet), respectively). Allegedly, the topographic conditions of the Chalklands would be more encouraging for the spread of scab than those of East Anglia and Kent, because hilly regions tend to be colder and wetter than lowlands.

In reality, and contrary to expectation, the correlation between elevation and mortality rates seems to have been negative: in other words, upland manors experienced lower mortality rates (Table 2). The lack of consistency in correlation between different regions implies that other variables need to be analysed.

Place Table 2 near here

\section{Spatial configuration and vegetation types of landscapes}

The spatial configuration of landscape attributes (namely, land-use distribution) was another decisive factor in determining the spread of scab. In our three case studies, the degree of each region's pastoralism varied. East Anglia and, especially, Norfolk were conspicuously pasturage-deficient and practiced a strongly arable-biased regime. Here, pasturage accounted for no more than 10 per cent of all land, while arable occupied about 57 per cent of the same (Broadberry et al. 2015). Kent was strongly a grain-producing region, deficient in grassland. Although its grassland share was larger than in East Anglia, it is unlikely that it exceeded 20 per cent of all land. Unlike in East Anglia, great sheep farms were largely unknown; even in the Romney Marsh region, the largest manorial flocks rarely exceeded several hundreds of animals. A different situation prevailed in the Chalklands, where arable land accounted for about 48 per cent of all land, yet the proportion of pasturage probably stood at only 35 per cent. In this region, sheep husbandry played a central role both before and after the Black Death, with some local lords, such as Bishop of Winchester and Winchester Cathedral Priory, holding massive flocks, often exceeding 1,000 per manor (Hare 2011). Local peasant families also seem to have held large flocks: a 1225 tax assessment shows that an averagely-taxed south Wiltshire family held 13 sheep (Postan 1962), considerably higher than elsewhere in the country.

In other words, a correlation between land-use and mortality rates seems to work only partially. While the pastoral bias of the Chalklands and the arable focus of Kent may explain the relative high and low mortality rates of those regions, the deficient grassland of East Anglia, which did not preclude intensive sheep farming, does not correlate with its comparatively high mortality rates. Unfortunately, the absence of statistical material from strongly pastoral counties such as Lancashire or Cornwall does not allow us to conclude to what degree land-use configuration and, consequently, vegetation types influenced the 
mortality rates. After all, those grass-rich counties practiced extensive sheep farming, contrary to grass-poor regions, such as East Anglia or Kent, where the type of livestock husbandry was much more intensive. Is it possible that those grassy regions practicing extensive sheep husbandry were actually not as much at risk as their arable-biased counterparts? The most important key-distinction between the two is stocking densities, which is another factor to be considered.

\section{Sheep stocking densities (per sown acres)}

Local producers grew crops in both 'arable' and 'pastoral' regions and even in the most infertile upland settlements a few acres of oats were cultivated. Whether cultivation was practiced in severalty or according to the 'open field' method, there was much reliance on animal manure as far as fallow land was concerned. Indeed, sheep manure was arguably the single most important fertilising agent, restoring nitrogen and, thus, contributing to land fertility (Newman 2002), and sheep had a strong presence on late-medieval English farms whether practicing intensive or extensive arable regimes. Depending on local agricultural structures and regimes, the stocking densities of sheep varied from place to place. Thicker stocking densities implied higher numbers of animals per land unit, which, in turn, may imply closer contacts between animals. In theory, one would expect to see a degree of correlation between stocking densities of sheep and their mortality rates. In reality, however, nothing could be further from truth (Table 3 ). In each instance, the correlation coefficient was minimal and the situation varied a great deal from place to place. For instance, a large sheeprearing manor of Agney (Kent), stocking 93 sheep units per 100 sown acres, lost only 11 per cent of its ovids. At the same time, Ospringe, in the same county, stocked only 1.5 sheep per 100 sown acres, yet, it lost 85 per cent of its ovids.

Place Table 3 near here

\section{Sheep stocking densities (per rural households)}

Dividing the livestock units by the number of sown acres is only one way to measure stocking densities. An alternative method is to multiply the number of animals per rural household by the approximate number of households per square mile. As late-medieval taxation records indicate, high human densities would imply also high animal stocking densities within parishes, and close contacts between flocks of different farms. This, in turn, would have, in theory, further facilitated the transmission of the disease.

Demographic congestion and poverty can play an enormous role in the dissemination of various diseases (e.g., Esteve-Gassent et al. 2014). By 1280, many regions of England seem to have nearly approached a demographic ceiling, with natural resources becoming less and less sufficient to feed their growing population. Although the figures can be debated, the total population of England c. 1280 stood at perhaps 4.9 million people. On average, the national average of population density may have been in the area of 100 people per square mile, but there were clear regional variances. Norfolk was the single most densely populated county in England, with perhaps 245 people per square mile in c.1280, while the figures for Cornwall, the most sparsely population county, stood at no more than some 27 per square mile (recalculated from Broadberry et al. 2015). 
As we have seen, the size of peasant sheep flocks varied from region to region. Although there was no 'national' census of livestock, surviving fragments of lay taxation suggest that Chalkland and north Suffolk peasants stocked over 10 sheep per household, which was considerably higher than their north Kentish counterparts holding about 6 sheep per family. Coupled with rural congestion, low living standards and omnipresent poverty, it is plausible that high stocking densities as measured in animal numbers per household were another factor facilitating the appearance and spread of scab. The connection between poor living conditions and disease outbreaks, in both humans and animals, is almost invariably taken for granted by historians and social scientists. During an outbreak of scab in South Africa in the 1890s, the disease was associated first and foremost with poverty and malnourishment of both humans and sheep (Beinart and Brown 2013). On the other hand, smaller peasant flocks in Kent, taken together with lower human population densities, may account for comparatively low mortality rates. Unfortunately, because of lack of demographic data on a parish level, it is impossible to establish any clear correlation between mortality rates and stocking densities per-household and this assumption remains a mere hypothesis.

\section{Composition of sheep flocks}

The composition of flocks is another factor to be taken into account. In absolute terms, wethers (castrated rams) were more susceptible to scab than sexually active mature sheep, despite being neutered animals and, thus, not engaging in close physical contacts with ewes. This was largely because wethers grew longer and heavier fleeces, which facilitate the dissemination of scab whether through direct contact with live mites or via shearing combs and cutters. This might be taken to mean that manors with larger proportions of wethers were more prone to scab than those, where breeding animals prevailed, but Table 4 indicates that this is another misleading impression. Again, the coefficient of correlation between the two variables was low and it varied a great deal across regions. The figures varied from manor to manor and there is no way to establish a clear correlation between the composition of ovine stocks and mortality rates.

Place Table 4 near here

\section{Regional wool quality}

In the late thirteenth century, the type and quality of English (and indeed, British) wool was determined by environmental conditions, rather than by breed. Although late-medieval commercial schedules listed wool types and prices primarily by county or regions, the quality could vary from place to place. None of the regions studied here could boast high quality wool: Chalkland flocks were producing medium-quality wool, East-Anglian poor quality woollens, while the quality of wool produced by Kentish sheep was among the poorest ones in the country, characterised by coarse and long fibres (Trowe-Smith 1957, Lloyd 1973, Munro 1978). Despite this, however, Kentish manors exhibited lower mortality rates compared to other regions. Although there is no way to establish wool quality on a manorial level, it appears that there was no correlation between wool type and fibre length and 
mortality rates. One way to explain this paradox is to consider the commercial demand for wool of different regions, in the context of concurrent urbanisation.

\section{Urbanisation and urban demand for wool}

At least in theory, urban development and the growth of an urban textile industry may have been another factor. Grains aside, wool was the single most demanded article of consumption both in towns and the countryside. By c.1280, the textile industry was still largely an urban phenomenon, regulated by local guilds (Munro 1999). In other words, there was much mutual dependence between towns and their rural hinterlands, with the countryside supplying raw wool and the towns producing finished articles of clothing. Apart from the domestic demand for wool, we also have to account for the international demand for English wool, in particular in western Mediterranean markets (Munro 2001). This meant frequent transportation of wool sacks from local producing centres to nearby towns and staple ports, which could be another indirect method of transmission of the disease.

The three regions in question each attained different rates of urbanisation, implying that the scale of urban demand differed across the regions; urbanisation and urban demand for wool, could thus be yet another factor. Relatively high urbanisation rates in East Anglia and the Chalklands may imply that local wool was shipped from the countryside to the town in larger volumes and more frequently, which would explain relatively high mortality rates. The comparatively low urbanisation rates of Kent, and insufficient international demand for its poor-quality wool, on the other hand, may hint why this county got away with lower mortality rates. At the same time, the impact of urbanisation and urban demand on mortality rates cannot, unfortunately, be directly quantified, because the accounts do not specify which manors sold their wool to local towns and to local staple ports.

\section{Local movement of sheep}

In addition to the transportation of wool from the countryside to towns, other factors caused the movement of live sheep, notably for inter-manorial flock management and to exploit common grazing rights.

As far as East Anglia and Kent are concerned, there is some evidence for the local movement of sheep primarily linked to inter-manorial management of large flocks. Twolarge north Norfolk sheep demesnes, Sedgeford and Gnatingdon, belonging to Norwich Cathedral Priory, were managed collectively. Similarly, St Benet's Abbey, another great Norfolk landlord, managed its extensive sheep flocks inter-manorially. In Kent, sheep pasture was shared between several pairs of manors belonging to Canterbury Cathedral Priory (Eastry and Lydden, Adisham and Knowlton, Ickham and Bramling), all in fair proximity to Canterbury. The frequent movement of sheep from place to place may, in some cases, have contributed to the spread of scab. Indeed, Sedgeford lost 728 out of 1,452 sheep, while Ickham lost 186 out of 373 animals. All the same, the extent of sheep transhumance in East Anglia and Kent should not be exaggerated: inter-manorial sheep management was rather limited, and it was 
usually practiced on those few demesnes, where sheep flocks exceeded 1,000 heads. Conversely, in the Chalklands, inter-manorial flock management was done on a much larger scale than East Anglia and Kent (Hare 2006).

In theory, inter-manorial management strategies aimed to ensure adequate reproduction rates and minimise the impact of temporary and local deficiencies. In reality, such movement could facilitate the spread of scab via direct transmission. Thus, around 11 November 1279 (Martinmas, the traditional feast of animal slaughter), 109 sheep were transferred to Patney (Wiltshire) from neighbouring manors. Similarly, Houghton (Hampshire) received 70 sheep from the neighbouring Michelmersh. These two manors lost 28 and 42 per cent of their flocks, respectively. On the other hand, Littleton, situated just 10 miles to the east of Houghton, received no sheep in the same year, yet, it lost 45 per cent of its flocks. In other words, the connection between inter-manorial transfer and mortality rates cannot always be taken for granted. Different patterns of geographic mobility may be another factor standing behind the mortality rates. The practice of inter-manorial management of ovine flocks in the Chalklands (and on a more limited scale in East Anglia in Kent) implied frequent movement of sheep from place to place. But then again, such correlation can only be appreciated at farm level, rather than by region or county.

Common grazing rights meant that peasant sheep were folded on the post-harvest portion of the demesne alongside the lord's animals. In theory, this would have entailed a close physical contact between animals and ensured a faster spread of the disease. However, establishing the connection between the existence/lack of common grazing rights and mortality rates is, at this point, next to impossible. We are in possession of some regional knowledge of field-system regulations, but no satisfactory information is available on a manorial basis. In an over-generalising manner, in the present sample, the East-Anglian and Chalkland manors practiced common grazing rights, but the situation in Kent is less clear (Hall 2014). It is possible that even though most land in Kent was cultivated in severalty, common grazing rights still existed in some parts of the north and east (Campbell 1981). This point remains, to my best knowledge, unproven, and if it is incorrect, then the hypothetical lack of common rights in Kent may partially explain the comparatively low mortality rates.

\section{Local management of scabious sheep}

A final factor to account for is the degree of managerial efficiency on individual manors. As Stone has shown, careful managerial strategies could have a strong impact on livestock health (Stone 2003). It should be borne in mind that a 'national' scab outbreak was a new reality and veterinarian knowledge on how to treat diseased sheep, based on rare local outbreaks, was very limited. Local sheep producers had to rely on various trial-and-error strategies, consisting primarily of the application of biological and chemical medicaments, including pig lard, ox fat, grease, horse salve, butter, oil, verdigris, quicksilver and copperas. In theory, the application of those medicaments may have reduced the mortality rates and controlled the disease. Yet with the possible exception of tar (still widely used as an anti-scab medicament by present day British farmers), these 'cures' only worked in some cases (Slavin 2015b).

The measures taken varied from place to place. The application of medicaments was a commonplace on the Chalkland manors of Winchester Cathedral Priory (of nineteen manors, 
twelve spent money on animal cures), but on Kentish and East Anglia manors this practice was quite uncommon. Only three Kentish manors (of twelve) - Lydden, Ickham and Ham and two (of fourteen) East Anglian manors - Attleborough in Norfolk and Nayland in Suffolk - purchased medicaments. But then again, with the exception of Lydden, which stocked almost 1,000 sheep and invested 16s 3d (and lost only 12 per cent of its flock), all other manors spent meagre sums. Interestingly, at Quickbury (Essex), local demesne managers spent money on lard for candles, but not for diseased sheep.

The degree of success varied from place to place. For instance, at Hannington (Hampshire) and Wroughton (Wiltshire), where local authorities spent rather generous sums on grease medicaments, the mortality rates were very low (12 per cent in each case). Barton Prior (Hampshire), which purchased no medicaments at all, lost 74 per cent of its large flock of 2,030 animals. At the same time, Whitchurch (in the same county) lost 89 per cent of its 1,240 sheep, despite the heavy investments in grease by local officials.

There were other possible responses to scab. Animal culling was carried out on a limited scale. For instance, at Sedgeford (Norfolk), local manorial officials slaughtered 117 sheep from of a total of 1,452), apparently to minimise the risk of the spread of the disease. Similarly, at Lower Halstow (Kent), 32 ovids (out of total 546) were butchered, because of their disease. But overall, such 'purging' strategy was quite uncommon and in the vast majority of cases, scabious sheep were doomed to die of the disease (Slavin 2015b).

Another strategy was to eliminate scabious sheep via 'panic sales'. Sales of diseased animals accounted for about four per cent of all animal losses, which is comparable with the figure of six per cent of animal losses through culling and sales, during the bovine panzootic of 1319-21. In both instances, the meat and skins of dead animals could not be used for consumption or tanning, and manorial accounts were clear in specifying that some animals were sold at low prices. As Table 5 indicates, the rates of 'panic sales' were above average in East Anglia and Kent. In all cases, however, the coefficient of variance across demesnes was too high, while the coefficient of correlation between the proportion of sold animals and mortality rates was too low. In other words, the panic sales had very limited or no impact on mortality rates and cannot, therefore, be to be taken seriously as a decisive factor: not even in the case of Kent, where relatively low mortality rates were not correlated to the attempts of local demesne managers to get rid of diseased animals.

Place table 5 here

Although the accounts do not specify who bought the diseased animals, their low prices hint that it was local tenants. Given the higher stocking densities of the tenancy sector (compared to the demesne one), the transfer of the diseased animals from the demesne to the peasant farms might have had harsh implications, as far as the spread of the disease goes. Although the 'panic sales' of diseased animals did not account for more than 4 per cent of all animal losses, it was potentially enough to transfer one or few scabious sheep from one place to another to facilitate an outbreak in a local flock. Is it possible, then, that mortality rates on those peasant farms that received sick animals via sales was even higher, when compared to adjacent demesnes? Unfortunately, the lack of comparable evidence from the tenant sector leaved this as hypothesis. 


\section{Conclusion}

A close analysis of mortality rates in English sheep flocks, based on a spatial approach, reveals remarkable difficulties in pinpointing a single, dominant or even multiple denominator to differences in mortality rates. In most cases, the results, expressed in coefficients of correlation between mortality rates and other explanatory variables, suggest that the situation was extremely complex, and cannot be reduced to a regional, let alone 'national', explanation. Furthermore, a very meticulous analysis of various conditions (both exogenous and endogenous) of each spatial observation, manor by manor, is required in order to appreciate this complexity. In one instance, a Hampshire manor might have ended up with light losses, thanks to the careful management of livestock by local officials and despite frequent movements of wool sacks to Southampton. This case, however, would not reflect the regional situation of the Chalklands, and the fate of its Kentish counterpart might have been altogether different again, because of its regional micro-climatic peculiarities, and the inefficient managerial strategies of local officers, despite the fact that local wool produce would not be transferred anywhere. But then again, this particular case would not be a microcosm of Kent as a whole: as we have seen, on average, Kentish demesnes suffered lower losses than other regions studied here.

Perhaps the most important conclusion to be drawn from this exercise is that we should not assume environmental, demographic, economic and institutional uniformity across regions but should appreciate regional and indeed local differences and complexity. It is imperative to 'break down' the analysis into smaller and diversified variables, in accordance with economic and ecological complexity models. Such approach spells out the premise that what matters most are very local conditions, on a individual parish/farm level. This model has proved to be valuable for quantitative historical research, as shown by Flaherty in a study of the geography of Great Irish Famine of 1845-52 (Flaherty 2014), and by Tesorieri in her study of human health in early-medieval Ireland, published in this volume. There are many more historical examples of environmental and biological shocks where such model could be applied with fruitful results; perhaps the most obvious one being the Black Death of 1348-51.

\section{References}

Bailey, M. 2007, Medieval Suffolk, 1200-1500: An Economic and Social History, Boydell and Brewer.

Bates P. 2007. 'Sheep scab (Psoroptes ovis)'. In Diseases of Sheep (Fourth Edition), ed. I. D. Aitken, Oxford University Press, 321-5.

Bates, D. and Liddiard, R. (eds.) 2013. East Anglia and its North Sea World in the Middle Ages, Boydel and Brewer.

Beinart, W. and Brown, K. 2013. African Local Knowledge and Livestock Health. Diseases and Treatments in South Africa, Wits University Press. 
Ben Ari, T., Neerincx, S., Gage, K.L., Kreppel, K., Laudisoit, A., Leirs, H. and Stenseth, N.C. 2011. Plague and Climate: Scales Matter, PLoS Pathog 7:9, e1002160.

Bisdorff, B., Milnes, A. and Wall, R. 2006. Prevalence and Regional Distribution of Scab, Lice and Blowfly Strike in Great Britain, Veterinary Record 158, 749-52.

Britnell, R.H. 1986. Growth and Decline in Colchester 1300-1525, Cambridge University Press.

Britton, C.E. 1937. A Meteorological Chronology to AD 1450, Meteorological Office (London).

Broadberry, S., Campbell, B.M.S., Klein, A., Overton, M. and van Leeuwen, B. 2015. British Economic Growth 1270-1870, Cambridge University Press.

Campbell, B.M.S. 1981. Commonfield origins - the regional dimension. In The Origins of Open Field Agriculture, ed. T. Rowley, Croom Helm.

Campbell, B.M.S. 2008. Benchmarking medieval economic development: England, Wales, Scotland, and Ireland circa 1290, Economic History Review 61, 896-945.

Campbell, B.M.S. 2016. The Great Transition: Climate, Disease and Society in the Late Medieval World, Cambridge University Press.

Carus-Wilson, E. and Coleman, O. 1963. England's Export Trade, 1275-1547, The Clarendon Press.

Coop, R.L., Barger, I. and Jackson, F. 2002. The Use of Macrocyclic Lactones to Control Parasites of Sheep and Goats. In Macrocyclic Lactones in Antiparasitic Therapy, eds. J. Vercruysse and R.S. Rew, Cab International, pp. 303-21.

Dawson, A.G., Hickey, K., Mayewski, P.A and Nesje, A. 2007. Greenland (GISP2) Ice Core and Historical Indicators of Complex North Atlantic Climate Changes during the Fourteenth Century, Holocene 17, 427-34.

Dunn, P. 2004. Trade. In Medieval Norwich, eds. C. Rawcliffe and R. Wilson, Hambledon and London, pp. 213-34.

Dyer. C. 1995. Sheepcotes: Evidence for Medieval Sheepfarming, Medieval Archaeology 39, 136-64.

Esteve-Gassent, M.D, Pérez de León, A.A., Romero-Salas, D., Feria-Arroyo, T.P., Patino, R., Castro-Arellano, I., Gordillo-Pérez, G., Auclair, A., Goolsby, J, Rodriguez-Vivas, R.I. and Estrada-Franco, J.G. 2014. Pathogenic landscape of transboundary zoonotic diseases in the Mexico-US border along the Rio Grande, Frontiers in Public Health, 17 November 2014 http://dx.doi.org/10.3389/fpubh.2014.00177.

Fay, I. 2015. Health and the City. Disease, Environment and Government in Norwich, 12001575. York Medieval Press. 
Flaherty, E., Assessing the distribution of social-ecological resilience and risk: Ireland as a case study of the uneven impact of famine, Ecological Complexity 19 (2014), 35-45.

Geltner, G. 2014. Healthscaping a Medieval City: Lucca's Curia viarum and the Future of Public Health History, Urban History 40, 395-415.

Hall, D. 2014. The Open Fields of England, Oxford University Press.

Hare, J. 2006. The Bishop and the Prior: demesne agriculture in medieval Hampshire, Agricultural History Review 54, 187-212

Hare, J. 2011. A Prospering Society: Wiltshire in the Later Middle Ages, University of Hertfordshire Press.

Jordan, W.C. 2009. Charms to Ward off Sheep and Pig Murrain. In Medieval Christianity in Practice, ed. M. Rubin, Princeton University Press, pp. 67-75.

Keene, D. 1985. Survey of Medieval Winchester, 2 vols., Oxford University Press.

Lambin, E.F., Tran A., Vanwambeke S. O., Linard, C and Soti V. 2010. Pathogenic Landscapes: Interactions between Land, People, Disease Vectors and their Animal Hosts, International Journal of Health Geographics 9: 54, http://doi.org/10.1186/1476-072X-9-54.

Lavigne, F. et al. 2013. Source of the Great A.D. 1257 Mystery Eruption Unveiled, Samalas Volcano, Rinjani Volcanic Complex, Indonesia, PNAS 110:42, pp. 16742-47.

Lloyd, T.H. 1973. The Movement of Wool Prices in Medieval England, Cambridge University Press, 1973.

Meintjes, T., Fourie, L.J. and Horak, I.G. 2002. On-host ecology and off-host survival of the sheep scab mite Psoroptes ovis, Onderstepoort Journal of Veterinary Research 69, 273-83.

Morimoto, N. 1977. The Sheep Farming of Norwich Cathedral Priory in the 13th and 14th Centuries, Nagoya Gakuin University Press.

Munro, J.H. 1978. Wool Price Schedules and the Qualities of English Wools in the Later Middle Ages, Textile History 9, 118-69.

Munro, J.H. 1999. The symbiosis of towns and textiles: urban institutions and the changing fortunes of cloth manufacturing in the Low Countries and England, 1270 - 1570, Journal of Early Modern History 3, 1-74.

Munro, J.H. 2001. New Institutional Economics' and the Changing Fortunes of Fairs in Medieval and Early Modern Europe: the Textile Trades, Warfare, and Transaction Costs, Vierteljahrschrift für Sozial- und Wirtschaftsgeschichte 88, 1-47. 
Muscheler, R., Joos, F., Beer J., Müller S.A., Vonmoos M. and Snowball I. 2007. Solar Activity during the Last $1000 \mathrm{yr}$ Inferred from Radionuclide Records, Quaternary Science Reviews 26, 82-97.

Newfield, T.P. 2009. A Cattle Panzootic in Early Fourteenth-Century Europe, Agricultural History Review 57, 155-190.

Newfield, T. P. 2013. Early Medieval Epizootics and Landscapes of Disease: The Origins and Triggers of European Livestock Pestilences, 400-1000 CE. In Landscapes and Societies in Medieval Europe East of the Elbe: Interactions between Environmental Settings and Cultural Transformations, eds. S. Kleingärtner, T. P. Newfield, S. Rossignol and D. Wehner, Pontifical Institute of Medieval Studies, pp. 73-113.

Newman, E. I. 2002. Medieval sheep-corn farming: how much grain yield could each sheep support?, Agricultural History Review 50, 164-80.

Postan, M. M. 1962. Village Livestock in the Thirteenth Century, Economic History Review $15,219-49$.

Potter, C., Simmons I., White, R., Williamson T., Winchester A.J.L. and Muir, R. The Foot and Mouth Outbreak, 2001: The Consequences for the Rural Landscapes in Britain, Landscapes 2 (2001), 3-28.

Rawcliffe, Carole, Urban Bodies: Communal Health in Late Medieval English Towns and Cities, Boydell and Brewer.

Stone, D. 2003. The Productivity and Management of Sheep in Late-medieval England, Agricultural History Review 51, 1-22.

Trow-Smith, R. 1957. A History of British Livestock Husbandry to 1700, Routledge and Kegan Paul.

Sigl, M. et al. 2015. Timing and Climate Forcing of Volcanic Eruptions for the Past 2,500 years, Nature, 523, 543-9.

Slavin, P. 2012. The Great Bovine Pestilence and Its Economic and Environmental Consequences in England and Wales, 1318-50, Economic History Review 65, 1239-66.

Slavin, P. 2015a. Peasant Livestock Husbandry in Late-Thirteenth-Century Suffolk: Economy, Environment and Society, in Peasants and Lords in Medieval English Economy: Essays in Honour of Bruce M.S. Campbell, eds. Maryanne Kowaleski, John Langdon and Phillipp R. Schofield (Turnhout: Brepols, 2015), pp. 3-26.

Slavin, P. 2015b. Flogging a Dead Cow: Coping with Animal Panzootics on the Eve of the Black Death. In Coping with Crisis: Re-Evaluating the Role of Crises in Economic and Social History, eds. A. Brown, A. Burn and R. Doherty, Boydell and Brewer, pp. 111-35.

Stothers, R.B., 2000. Climatic and Demographic Consequences of the Massive Volcanic Eruption of 1258, Climatic Change, 45, 361-74. 